J. Dairy Sci. 92:5011-5018

doi:10.3168/jds.2008-1769

(c) American Dairy Science Association, 2009.

\title{
Meta-analysis of milk protein yield responses to lysine and methionine supplementation
}

\author{
D. Vyas and R. A. Erdman ${ }^{1}$ \\ Animal and Avian Sciences Department, University of Maryland, College Park 20742
}

\begin{abstract}
Previous reports on milk protein responses to AA supplementation focused on Lys and Met concentrations expressed as a percentage of metabolizable protein, not the amounts of AA supplied. The objective of this study was to quantify the milk protein yield (MPY; g/d) response in studies in which Met or Lys was supplied either by postruminal infusion or in a rumen-protected form. A meta-analysis using a logistic regression model fitted using nonlinear mixed model procedures was performed on results from 23 published studies involving postruminal supplementation of Lys (18 experiments) and Met (35 experiments) in lactating dairy cows. Variance caused by study effect was removed by designation of individual study as subject within the random component within the nonlinear model. Milk protein responses to supplemental Met decreased from 16 to $4 \mathrm{~g}$ of milk protein per gram of metabolizable Met intake as Met intake varied from 25 to $70 \mathrm{~g}$ per cow per day. Similarly, milk protein responses to supplemental Lys decreased from 5.0 to $3.2 \mathrm{~g}$ of milk protein per gram of metabolizable Lys intake as Lys intake varied from 80 to $203 \mathrm{~g}$ per cow per day. Assuming Met and Lys concentrations of 2.76 and $7.63 \mathrm{~g} / 100 \mathrm{~g}$ of milk protein, respectively, the implied marginal efficiencies of metabolizable AA use for MPY decreased from 44 to $12 \%$ for Met and from 39 to $25 \%$ for Lys over the range of metabolizable AA intakes. Although the estimated efficiencies were low compared with previous estimates, a low marginal efficiency of amino acid utilization would be expected when amino acid supply is at or near to the animal's requirement, as was the case in these experiments. This suggests that current models that assume both a constant MPY response and constant AA utilization efficiency are inadequate. Models that assume a constant efficiency of AA use will overestimate production responses to individual AA supply, especially when high amounts of metabolizable AA are fed.
\end{abstract}

Received September 30, 2008

Accepted June 17, 2009.

${ }^{1}$ Corresponding author: erdman@umd.edu
Key words: meta-analysis, lysine, methionine, milk protein

\section{INTRODUCTION}

The Federal Milk Marketing Administration (AMSUSDA, 1999) adopted the multiple component pricing system (MCP) that is used in the majority of the federal milk marketing orders during calendar year 2000. The MCP system structurally changed producer milk pricing from a previous system based on milk volume adjusted for milk fat content to one based primarily on the amounts of milk fat, protein, and other solids (lactose plus minerals) produced. Of the major milk components, protein and fat are economically most important to dairy producers. As the value of milk protein increased dramatically during 2007 (AMS-USDA, 2009), there has been a greater interest among dairy producers in nutritional modifications such as AA supplementation that will increase milk protein output (Schwab and Boucher, 2008). Concurrent with increased milk protein output, there is a need to improve conversion efficiency of dietary nitrogen into milk protein (Lapierre et al., 2005). This approach would not only help in controlling environmental pollution, but would also reduce the feed cost to further improve the margins of profitability for dairy farmers (Lapierre et al., 2005).

Studies have suggested that Lys and Met are the most limiting AA for milk protein synthesis in dairy cows fed corn silage and alfalfa-based commercial diets typically used in the United States and that optimal concentrations of these limiting AA are required in MP to increase milk protein synthesis (Schwab et al., 1976). Thus, balancing for these AA is of practical significance as a means to enhance milk protein production and to improve efficiency of milk protein synthesis (Cho et al., 2007). Using an indirect dose response approach, Rulquin et al. (1993) found that optimal concentrations for Lys and Met were 7.3 and 2.5\%, respectively, of protein digested in the intestine. Using a similar approach, NRC (2001) suggested optimal concentrations of Lys and Met at 7.2 and $2.4 \%$ of MP, respectively. However, expression of nutrient requirements as dietary concentrations suffers from an inherent error associated 
with variability in level of feed intake. If feed consumption is less than expected, a higher concentration of a nutrient (in this case, AA) is required to consume the same amount of that nutrient. Conversely, if feed consumption is greater than expected, then these AA will be overfed in relation to the dairy cow's needs and will be poorly utilized. The present study was conducted with the objective of determining the milk protein yield response to the amounts (g/d) of supplemental Lys and Met rather than expressing responses as a function of dietary concentrations.

\section{MATERIALS AND METHODS}

The input data set was prepared using treatment means from 23 published studies in which supplemental Met (35 experiments; 99 treatments) or Lys (18 experiments; 53 treatments) was either provided in rumen-protected form or infused into the abomasum or duodenum. Individual data sets were created for Met and Lys. Within experiment, only those treatment combinations that contained an adequate control for each amino acid were used. Controls included treatments in which either the diet was not supplemented or the treatment varied only by the amount of an individual amino acid (Lys or Met) being tested. In data sets in which milk CP concentration was reported rather than true protein, milk true protein was calculated as $0.93 \times$ milk CP, similar to the approach in calculating the milk true protein component for milk energy values used by NRC (2001).

Metabolizable Lys and Met were estimated from individual treatment means for DM intake, corresponding individual feed ingredient intakes, and cow information from each published study using the NRC (2001) software. Contributions to metabolizable AA (MAA) from supplemental AA were added to the predicted flows of digestible AA assuming $100 \%$ intestinal availability for infused AA. The availability for rumen-protected AA was calculated as per NRC $(2001 ; 81 \%$ for rumenprotected AA with polymers in the surface coating and $60 \%$ for Ketionin, rumen-protected Met, Rumen Kjemi, Oslo, Norway). Treatments in which Lys or Met were potentially limiting were avoided to not confound limitations of one amino acid with the response to the other. The data set for Lys included only those observations in which Met was more than $1.95 \%$ of MP, and the data set for Met included only those observations in which Lys was greater than $6.5 \%$ of the MP. These were the same criteria used by the NRC (2001). This reduced the total treatment observations in the data sets for Met and Lys to 67 and 41 observations, respectively. Details on the studies and levels of DM intake, milk production, and milk protein yields are in Table 1 .
A logistic model described by Doepel et al., (2004) was used to estimate the interrelationship between milk protein yields (MPY; g/d) and estimated intakes (g/d) of individual MAA (Lys or Met). Because the data set was prepared from 23 separate published studies, it was important to account for variance caused by experiment. In this instance, individual experiments were considered as random samples from a larger set of the population (St-Pierre, 2001). Inclusion of experiment effects in the logistic model required estimation of both the fixed effects associated with the nonlinear model parameters and the random effects of experiment. Therefore, the Nonlinear Mixed procedure (NLMIXED) of SAS 9.1 (SAS Inst. Inc., Cary, NC) was used to fit the model. This was analogous to the approach for fitting a breakpoint model described in Robbins et al. (2006). The fixed effect component $\left(\mathrm{MPY}_{\text {fixed }}\right)$ of MPY on MAA was estimated using the logistic model:

$$
\mathrm{MPY}_{\text {fixed }}=\frac{\mathrm{A}}{\left(1+\mathrm{Be}^{-(\mathrm{MAA} / \mathrm{k})}\right)}
$$

where $\mathrm{A}=$ ceiling of the milk protein yield response ( $\mathrm{g} / \mathrm{d}), \mathrm{B}=$ amplitude of the curve, $\mathrm{k}=$ steepness of the curve, and MAA = individual metabolizable AA (Lys or Met) intake (g/d).

Random effects of experiment and MPY fixed and their variance components were estimated using the following MODEL and RANDOM SAS programming statements:

MODEL MPY Normal(E + MPY fixed, Errvar);

$$
\begin{gathered}
\text { RANDOM E } \sim \operatorname{Normal}(\mathbf{0}, \text { Exptvar }) \text { Subject }= \\
\text { Experiment. }
\end{gathered}
$$

Model-predicted MPY was the sum of the random effects of experiment $(\mathbf{E})$ and fixed logistic model effects $\left(M Y_{\text {fixed }}\right)$ that were assumed to be normally distributed with a variance (Errvar). The effect of $\mathrm{E}$ was estimated using the RANDOM statement within SAS and assumed a normal distribution with a mean of zero and a variance (Exptvar). Generated models were validated by plotting residuals (observed minus predicted) against predicted values of MPY to test for prediction bias (St-Pierre, 2003) and the magnitude of the model root mean square error (RMSE).

\section{RESULTS AND DISCUSSION}

Parameter estimates for logistic model components, Errvar, Exptvar, and model RMSE are in Table 2. Ceil- 
Table 1. Descriptive data for studies used to prepare the data sets for determining milk protein responses to Lys and Met supplementation

\begin{tabular}{|c|c|c|c|c|c|c|c|c|c|c|c|c|}
\hline \multirow[b]{2}{*}{ Study } & \multicolumn{3}{|c|}{ DM intake, $\mathrm{kg} / \mathrm{d}$} & \multicolumn{3}{|c|}{ Milk, kg/d } & \multicolumn{3}{|c|}{ Milk protein, $\%$} & \multicolumn{3}{|c|}{ Milk protein, g/d } \\
\hline & Mean \pm SD & Median & Range & Mean $\pm \mathrm{SD}$ & Median & Range & Mean \pm SD & Median & Range & Mean \pm SD & Median & Range \\
\hline Armentano et al., 1997 & $25.9 \pm 0.2$ & 25.9 & 0.4 & $41.5 \pm 0.2$ & 41.4 & 0.4 & $2.97 \pm 0.05$ & 2.96 & 0.12 & $1,223 \pm 25$ & 1,226 & 59 \\
\hline Casper et al., 1987 & $21.1 \pm 0.8$ & 21.1 & 1.1 & $35.1 \pm 0.0$ & 35.1 & 0.0 & $2.88 \pm 0.04$ & 2.88 & 0.06 & $1,011 \pm 15$ & 1,011 & 21 \\
\hline Casper and Schingoethe, 1988 & $17.8 \pm 0.1$ & 17.7 & 0.1 & $30.1 \pm 0.4$ & 30.1 & 0.5 & $2.81 \pm 0.08$ & 2.81 & 0.12 & $844 \pm 16$ & 844 & 22 \\
\hline Guinard and Rulquin, 1994b & $16.8 \pm 0.2$ & 16.9 & 0.4 & $21.9 \pm 0.3$ & 21.8 & 0.7 & $3.14 \pm 0.04$ & 3.14 & 0.10 & $688 \pm 15$ & 691 & 32 \\
\hline Illg et al., 1987 & $20.2 \pm 1.3$ & 20.2 & 1.8 & $34.1 \pm 1.6$ & 34.1 & 2.3 & $3.03 \pm 0.05$ & 3.03 & 0.07 & $1,025 \pm 63$ & 1,025 & 90 \\
\hline King et al., 1991 & $21.5 \pm 1.8$ & 22.7 & 3.9 & $29.5 \pm 2.1$ & 29.9 & 5.7 & $3.24 \pm 0.06$ & 3.25 & 0.19 & $953 \pm 73$ & 960 & 214 \\
\hline Munneke et al., 1991 & $20.0 \pm 1.1$ & 20.0 & 1.6 & $34.4 \pm 0.9$ & 34.4 & 1.2 & $3.00 \pm 0.03$ & 3.00 & 0.04 & $1,030 \pm 14$ & 1,030 & 20 \\
\hline Papas et al., 1984 & $20.5 \pm 0.8$ & 20.5 & 2.1 & $34.0 \pm 0.6$ & 34.0 & 1.5 & $2.93 \pm 0.05$ & 2.93 & 0.13 & $984 \pm 18$ & 984 & 49 \\
\hline Piepenbrink et al., 1999 & $24.6 \pm 0.3$ & 24.5 & 0.8 & $40.9 \pm 1.0$ & 41.0 & 2.8 & $3.09 \pm 0.09$ & 3.10 & 0.20 & $1,260 \pm 66$ & 1,276 & 173 \\
\hline Piepenbrink et al., 2004 & $19.4 \pm 0.6$ & 19.4 & 1.2 & $43.0 \pm 1.4$ & 42.0 & 3.1 & $2.82 \pm 0.05$ & 2.80 & 0.11 & $1,190 \pm 24$ & 1,190 & 60 \\
\hline Pisulewski et al., 1996 & $22.8 \pm 0.4$ & 22.9 & 0.9 & $37.1 \pm 0.7$ & 37.1 & 1.6 & $2.85 \pm 0.11$ & 2.86 & 0.25 & $1,055 \pm 32$ & 1,054 & 85 \\
\hline Polan et al., 1991 & $19.6 \pm 0.8$ & 19.5 & 2.0 & $30.1 \pm 4.1$ & 30.5 & 9.9 & $3.03 \pm 0.12$ & 3.04 & 0.36 & $891 \pm 111$ & 880 & 290 \\
\hline Rogers et al., 1987 & $21.8 \pm 0.5$ & 21.8 & 1.2 & $29.8 \pm 0.8$ & 30.1 & 2.0 & $3.09 \pm 0.04$ & 3.08 & 0.12 & $915 \pm 31$ & 920 & 90 \\
\hline Rulquin and Delaby, 1994 & $21.3 \pm 0.6$ & 21.3 & 1.3 & $30.2 \pm 1.0$ & 30.2 & 2.8 & $3.29 \pm 0.08$ & 3.30 & 0.24 & $985 \pm 26$ & 985 & 80 \\
\hline Rulquin and Delaby, 1997 & $19.3 \pm 1.0$ & 19.3 & 1.7 & $29.0 \pm 0.5$ & 29.1 & 1.2 & $3.17 \pm 0.07$ & 3.19 & 0.16 & $920 \pm 26$ & 920 & 60 \\
\hline Schingoethe et al., 1988 & $20.6 \pm 0.8$ & 20.8 & 2.3 & $34.0 \pm 1.4$ & 34.1 & 4.0 & $2.94 \pm 0.07$ & 2.92 & 0.20 & $999 \pm 29$ & 999 & 69 \\
\hline Schwab et al., 1976 & $18.6 \pm 1.2$ & 18.6 & 4.2 & $27.6 \pm 2.8$ & 28.6 & 9.2 & $2.98 \pm 0.10$ & 3.00 & 0.43 & $815 \pm 87$ & 841 & 329 \\
\hline Schwab et al., 1992a & $19.6 \pm 1.3$ & 19.8 & 4.2 & $29.7 \pm 4.8$ & 31.6 & 14.8 & $3.07 \pm 0.15$ & 3.06 & 0.52 & $895 \pm 121$ & 941 & 401 \\
\hline Schwab et al., $1992 \mathrm{~b}$ & $20.6 \pm 1.4$ & 21.3 & 4.1 & $31.4 \pm 7.2$ & 32.9 & 19.2 & $2.89 \pm 0.13$ & 2.87 & 0.49 & $896 \pm 179$ & 93 & 508 \\
\hline Socha et al., 1994a & $25.6 \pm 0.4$ & 25.8 & 0.9 & $38.3 \pm 0.1$ & 38.2 & 0.3 & $3.30 \pm 0.06$ & 3.30 & 0.17 & $1,252 \pm 26$ & 1,260 & 72 \\
\hline Socha et al., 1994b & $25.6 \pm 0.5$ & 25.5 & 1.2 & $34.5 \pm 0.6$ & 34.5 & 1.2 & $3.45 \pm 0.07$ & 3.46 & 0.17 & $1,192 \pm 18$ & 1,190 & 40 \\
\hline Socha et al., 2008 & $24.1 \pm 2.2$ & 25.4 & 5.4 & $37.6 \pm 2.4$ & 38.2 & 7.0 & $3.10 \pm 0.16$ & 3.09 & 0.48 & $1,151 \pm 36$ & 1,137 & 122 \\
\hline Yang et al., 1986 & $20.6 \pm 0.6$ & 20.6 & 0.8 & $34.9 \pm 0.5$ & 34.9 & 0.7 & $2.91 \pm 0.04$ & 2.91 & 0.05 & $1,011 \pm 29$ & 1,011 & 41 \\
\hline
\end{tabular}


Table 2. Logistic model parameter estimates $( \pm \mathrm{SE})$ and model root mean square error for Lys and Met supplementation on milk protein yield $(\mathrm{g} / \mathrm{d})$

\begin{tabular}{lcc}
\hline Parameter $^{1}$ & Met & Lys \\
\hline $\mathrm{A}$ & $1,311 \pm 143$ & $1,501 \pm 274$ \\
$\mathrm{~B}$ & $2.58 \pm 1.41$ & $3.90 \pm 0.96$ \\
$\mathrm{k}$ & $19.95 \pm 9.17$ & $73.95 \pm 23.66$ \\
Experiment variance & $13,001 \pm 1,369$ & $11,001 \pm 2,439$ \\
Model variance & $3,001 \pm 1,369$ & $501 \pm 659$ \\
Root mean square error & 23.8 & 6.0 \\
\hline
\end{tabular}

${ }^{1} \mathrm{~A}=$ ceiling of the milk protein yield response $(\mathrm{g} / \mathrm{d}) ; \mathrm{B}=$ amplitude of the curve; $\mathrm{k}=$ steepness of the curve.

ings for milk protein response (A) were 1,311 and 1,501 $\mathrm{g} / \mathrm{d}$, respectively, for Met and Lys. These were 117 and $407 \mathrm{~g} / \mathrm{d}$ greater than those estimated by Doepel et al. (2004). However, mean MPY in our data set was greater $(1,058$ and $921 \mathrm{~g} / \mathrm{d}$ for Met and Lys data sets, respectively) than the mean MPY $(738 \mathrm{~g} / \mathrm{d})$ in their data set. Higher asymptotes (ceilings) for milk protein production would be expected with higher milk protein production in the data set and the levels predicted were within expected ranges for today's dairy cows.

Another factor related to the ceiling could be the nature of data sets used in our study compared with that of Doepel et al. (2004). In Doepel et al. (2004), experiments using rumen-protected AA were specifically excluded because of the uncertainty of predicting their MAA contribution. Also, they used several experiments in which casein was infused postruminally. Because our objective was to measure responses to individual MAA (Met and Lys), this contributed to the considerable differences between the 2 data sets. The parameter estimates for B were lower (2.6 and 3.9 vs. 4.3 and 6.7, respectively), whereas those for $\mathrm{k}$ were higher (20 and 74 vs. 18 and 44, respectively) for both Met and Lys compared with those of Doepel et al. (2004). These differences might be expected because our model had a greater asymptotic predicted MPY and potentially, a larger range in Met and Lys MAA intakes.

Residual plots for model predictions and the relationship between model-predicted and experiment-adjusted MPY are shown in Figures 1, 2, 3, and 4. For Met, there was a slope bias for MPY prediction $(P>0.01$; Figure 1) in which residuals tended to be negative at low levels of predicted MPY. Most of the linear bias could be attributed to 2 treatment means in which MPY was overestimated (strongly negative residuals). However, most residuals were less than $25 \mathrm{~g} / \mathrm{d}$, which would be equivalent to less than $2.5 \%$ of the mean MPY. For Lys, there was no evidence of prediction bias as shown in the residual plot (Figure 2). Plots of model-predicted versus milk protein yield adjusted for experiment suggest that the models fit the data sets well and that

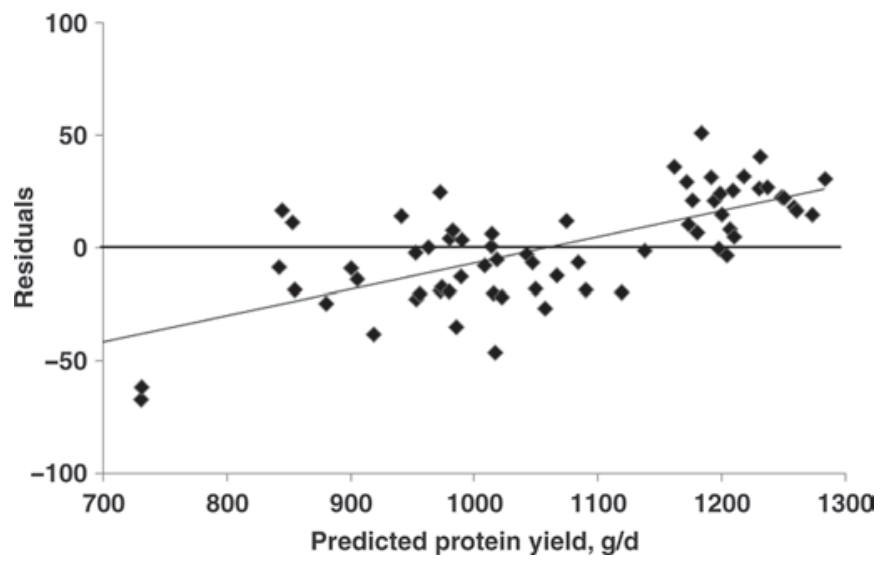

Figure 1. Plot of residuals against predicted milk protein yield in response to Met supplementation. There was a linear bias where residual $=0.101( \pm 0.0164) \times$ predicted milk protein $-105.5( \pm 17.8$; $\left.\mathrm{R}^{2}=0.38, P<0.01\right)$.

any bias was minimal in relation to the range in MAA intakes and MPY. Finally, RMSE of 24 and $6 \mathrm{~g} / \mathrm{d}$ for Met and Lys, respectively, were small compared with the 626 to $1,314 \mathrm{~g} / \mathrm{d}$ range in MPY across the 2 data sets. Therefore, we believe that the model adequately fit the Met and Lys data sets.

Figures 5 and 6 illustrate the effect of Met and Lys intake on marginal rates of milk protein production and their efficiency of conversion into milk AA. Methionine and Lys concentrations of 2.76 and $7.63 \mathrm{~g}$ per $100 \mathrm{~g}$ of milk protein (Jensen, 1995) were used to estimate milk Met and Lys yields from model-predicted MPY, and efficiencies of use were calculated from model-predicted milk AA divided by MAA intake.

As daily Met intake varied from 25 to $70 \mathrm{~g} / \mathrm{cow}$, marginal MPY response decreased from 16 to $4 \mathrm{~g}$ of milk protein/g of metabolizable Met intake. As daily

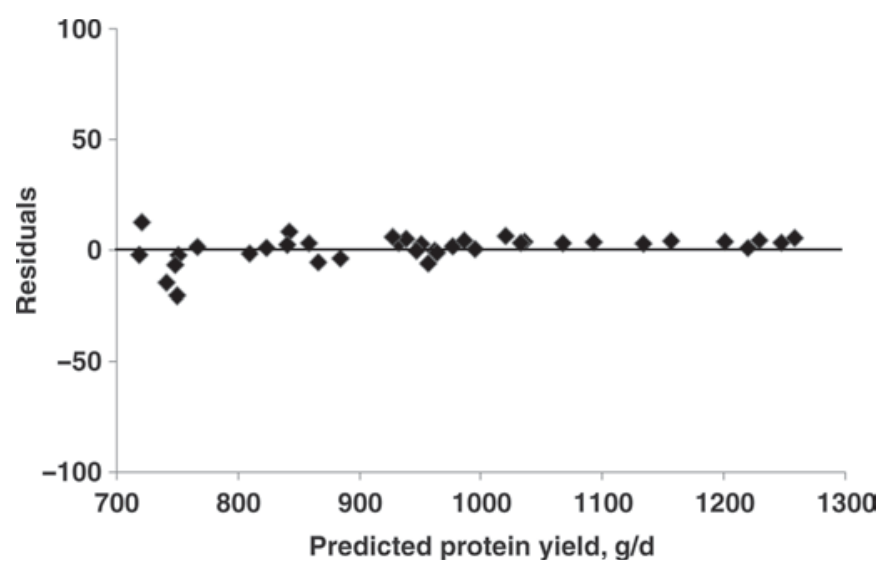

Figure 2. Plot of residuals against predicted milk protein yield in response to Lys supplementation. There was no mean or linear bias $(P>0.05)$. 


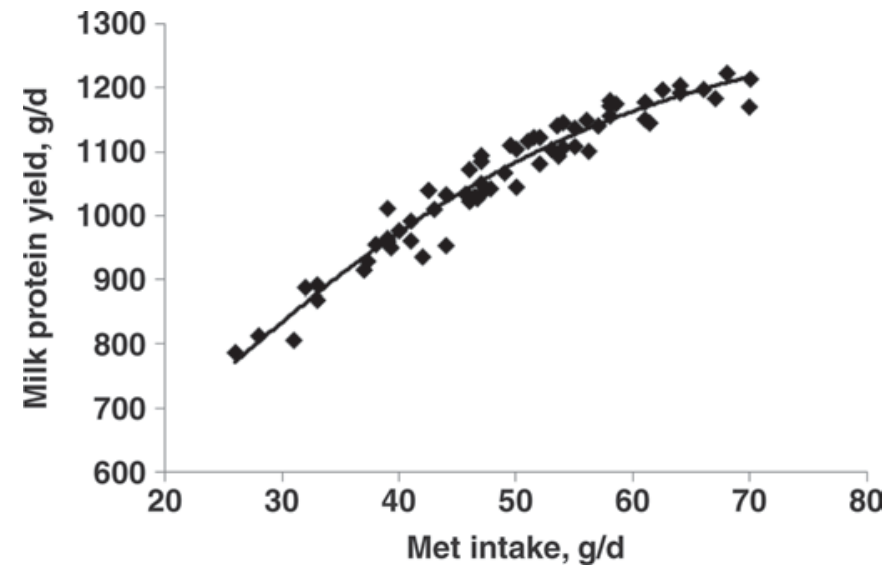

Figure 3. Plot of experiment adjusted milk protein yield $(\mathrm{g} / \mathrm{d})$ versus model-predicted milk protein yield (solid line) response to Met intake $(\mathrm{g} / \mathrm{d})$.

Lys intake varied from 80 to $203 \mathrm{~g} /$ cow, marginal MPY responses decreased from 5.0 to $3.2 \mathrm{~g}$ of milk protein $/ \mathrm{g}$ of metabolizable Lys intake. Accurate predictions of MPY response are critical to economic decisions on the use of rumen-protected AA in dairy cattle feeding programs (Cho et al., 2007). For Met, the predicted MPY response can be compared between the present model, that of Doepel et al. (2004), and values derived indirectly from prediction data of Cho et al. (2007; Table 3).

Model-predicted MPY was lower for Doepel et al. (2004), whereas those of Cho et al. (2007) were higher compared with those predicted by the model in this study. Although predicted values were substantially different between studies, the magnitudes of the MPY responses were remarkably similar. For example, increasing Met intake from 41.6 to $53.8 \mathrm{~g} / \mathrm{d}$ resulted in a

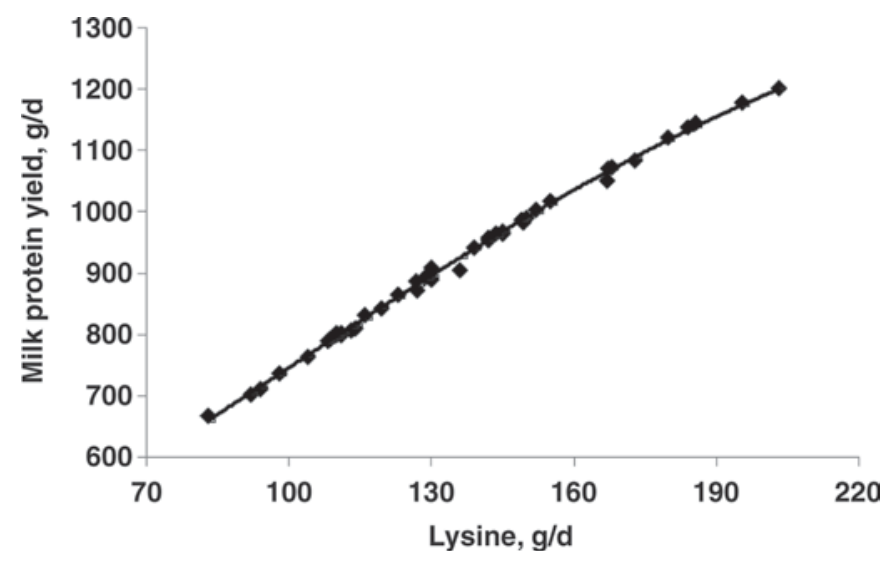

Figure 4. Plot of experiment adjusted milk protein yield $(\mathrm{g} / \mathrm{d})$ versus model-predicted milk protein yield (solid line) in response to Lys intake $(\mathrm{g} / \mathrm{d})$.
123,144 , and $140 \mathrm{~g}$ increase in MPY for the model from this study, Doepel et al. (2004), and Cho et al. (2007), respectively. The respective predicted MPY responses for increasing Met intake from 43.3 to $54.4 \mathrm{~g} / \mathrm{d}$ were 109, 127, and $111 \mathrm{~g} / \mathrm{d}$. Although there was relatively poor agreement on the absolute amounts of predicted MPY between models, the direction and the magnitude of the responses were in reasonably good agreement.

Although contributing experiments in our data set and that of Cho et al. (2007) were likely similar, several differences in the approach were used in predicting MPY. First, Cho et al. (2007) predicted changes in milk protein concentration, not MPY, which assumed that milk yield would not vary with AA supplementation. We based our model on MPY directly, which is the method of payment to dairy producers in the MCP system used by several federal milk marketing orders. Second, their modeling approach utilized a Box-Cox model compared with the logistic model approach in this study and that of Doepel et al. (2004). Finally, we were able to remove study effect (St-Pierre, 2001), which was not the case for Cho et al. (2007) or Doepel et al. (2004).

Estimated efficiency of use of MAA for milk AA output decreased from 44 to $12 \%$ for Met and from 39 to $25 \%$ for Lys over the range of AA intakes used for model prediction (Figures 5 and 6). Calculated marginal efficiencies substituting the logistic model coefficients of Doepel et al. (2004) suggest marginal efficiencies decreasing from 46 to $14 \%$ for Met and from 47 to $11 \%$ for Lys over the same range of MAA intakes. These data show that both MPY responses and the efficiency of use of Met and Lys for milk protein production vary continuously and decrease with increasing AA intake. Previous experiments have also shown that efficiency of protein use for milk protein synthesis decreases as the supply is increased (Whitelaw et al., 1986; Guinard et al., 1994). Wang et al. (2007) also observed reduced nitrogen efficiency with increased levels of dietary MP. These observations point toward an inherent limitation with NRC's use of a fixed factor of 0.67 for conversion of MP to milk protein (NRC, 2001). Contrary to Doepel et al. (2004), the marginal efficiency in our study was calculated without accounting for AA required for maintenance function because it can be argued that differences in maintenance costs might be a component of study effects and therefore would have already been removed in our model. Thus, the marginal increment in milk AA per increment in MAA would represent the true efficiency of utilization above maintenance requirements.

Poor conversion efficiency of MAA can be attributed to several factors including energy limitation, especially at higher levels of AA supplementation. Here, supple- 
Table 3. Comparison of models' predicted milk protein yield responses to supplemental metabolizable Met in the present and Doepel et al (2004) logistic models and the implied milk protein responses derived from work of Cho et al. (2007)

\begin{tabular}{lrcc}
\hline & \multicolumn{3}{c}{ Model } \\
\cline { 2 - 4 } $\begin{array}{l}\text { Met intake, } \\
\text { g/d }\end{array}$ & $\begin{array}{r}\text { Logistic } \\
\text { present }^{1}\end{array}$ & $\begin{array}{r}\text { Logistic (Doepel } \\
\text { et al., 2004) }\end{array}$ & $\begin{array}{c}\text { (Cho et al., } \\
2007)\end{array}$ \\
\hline $41.6^{2}$ & 993 & 837 & 1,052 \\
$53.8^{2}$ & 1,117 & 981 & 1,192 \\
$56.7^{2}$ & 1,139 & 1,007 & 1,205 \\
$43.3^{3}$ & 1,013 & 860 & 1,047 \\
$54.4^{3}$ & 1,122 & 987 & 1,158 \\
$56.5^{3}$ & 1,138 & 1,006 & 1,171 \\
\hline
\end{tabular}

${ }^{1}$ Using logistic model and regression coefficients from Table 2.

${ }^{2}$ Corresponding to $1.8,2.32$, and $2.40 \%$ Met ( $\%$ of MP) in Cho et al. (2007).

${ }^{3}$ Corresponding to $1.9,2.34$, and $2.42 \%$ Met (\% of MP) in Cho et al. (2007).

mented AA would be partitioned toward complete oxidation for energy generation rather than being used for milk protein synthesis (Bequette, 2002; Lapierre et al., 2006). Another factor contributing toward low MAA efficiency would include losses of AA caused by incomplete reabsorption of endogenous secretions. The efficiency of absorption of endogenous secretions is not always $100 \%$, resulting in losses of AA present in those secretions. Van Bruchem et al. (1997) showed that 50\% of endogenous secretions end up in feces. Direct oxidation of AA by gut epithelial cells would also result in reduced availability of AA (Lapierre et al., 2006). Berthiaume et al. (2001) observed that only $62 \%$ of Met and $72 \%$ of Lys appeared in portal-drained viscera compared with mesenteric-drained viscera, with an average of $66 \%$ appearance for all essential AA. Berthiaume et al. (2001) attributed a fraction of this loss to gut oxidation. Similarly, Lobley et al. (2003) observed oxidation of Met at $10 \%$ of portal absorption.

Postabsorptive effects involving hepatic and mammary metabolism further increase losses of AA. Lobley and Lapierre (2003) observed that AA such as Met, Phe, and His were removed by the liver in significant amounts. Lapierre et al. (2005) observed 38\% hepatic removal from net portal absorption of Met in dairy cows. Amino acids removed by the liver can be oxidized or used for synthesis of export proteins (Bequette, 2002). Mabjeesh et al. (2000) observed that Lys oxidation increased from 20 to $34 \%$ of total Lys extracted by mammary gland with Lys and Met infusion, suggesting an increase in the oxidative pathway for disposal of excess AA by the mammary gland. These observations point to the fact that the amounts and profile of AA at the site of absorption are most likely different from the amounts and profile of AA delivered to the mammary

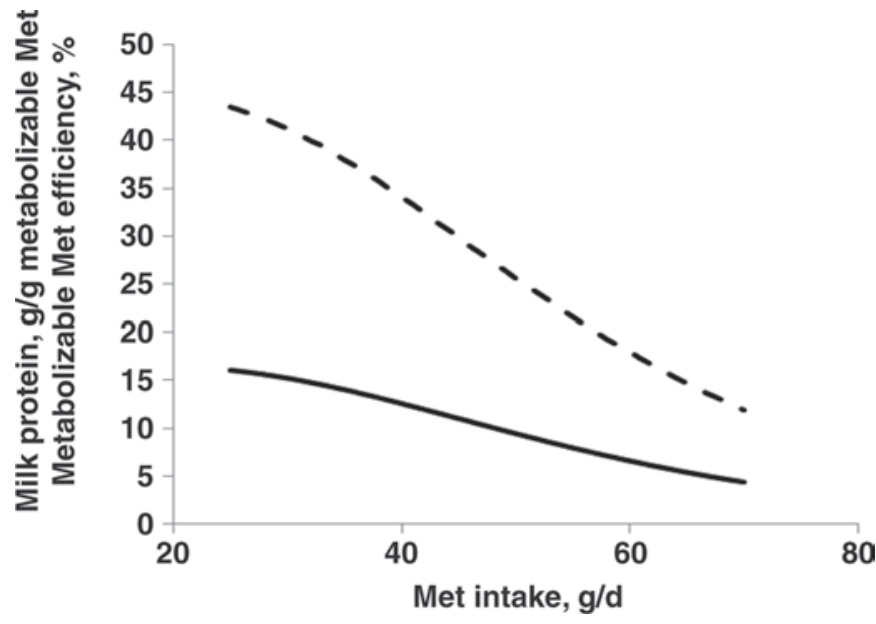

Figure 5. Predicted marginal milk protein yield response (g) per gram of Met intake (solid line) and the efficiency of utilization of metabolizable Met (dashed line) for milk protein synthesis in relation to increasing metabolizable Met intake $(\mathrm{g} / \mathrm{d})$.

gland, which would affect the conversion efficiency of MAA. Thus, in establishing requirements for efficient milk protein synthesis, AA metabolism should be studied at every step of its utilization (Pacheco et al., 2006) and should account for differences in dietary composition and metabolic events (Raggio et al., 2004).

In summary, the meta-analysis of MPY response to AA supplementation allowed determination of the amounts of milk protein from the amounts of supplemental Lys and Met fed rather than from their concentrations in MP (NRC, 2001; Cho et al., 2007). This would correct for errors caused by variation in feed intake. This approach also predicts protein yield directly, rather than

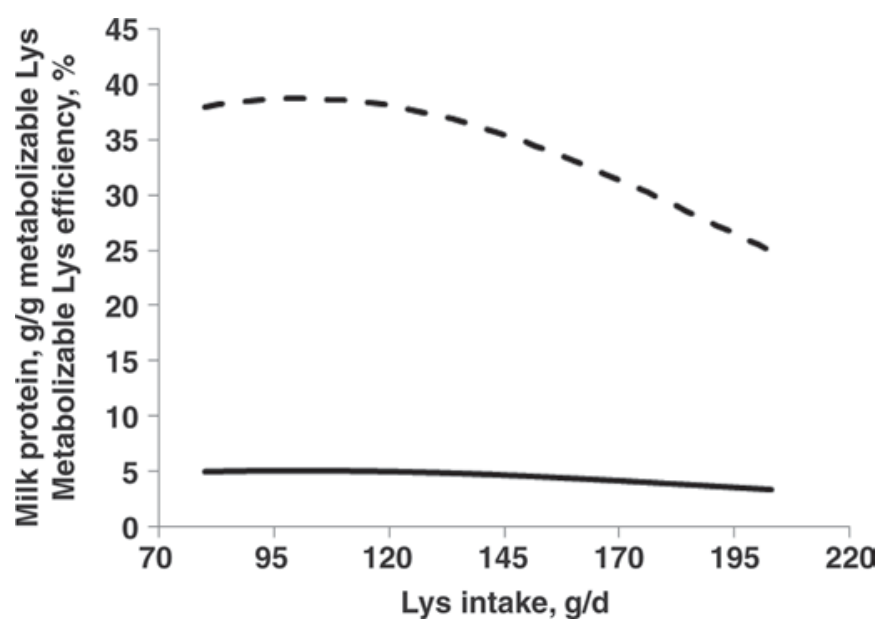

Figure 6. Predicted marginal milk protein yield response (g) per gram of Lys intake (solid line) and the efficiency of utilization of metabolizable Lys (dashed line) for milk protein synthesis in relation to increasing metabolizable Lys intake $(\mathrm{g} / \mathrm{d})$. 
indirectly from changes in milk protein concentration (Cho et al., 2007), thereby reducing the error associated with fluctuations in milk production. We observed drastic declines in conversion efficiency of MAA into milk protein with increasing Met and Lys intakes. This suggests that accounting for the decreasing marginal efficiency of AA use should be a very important consideration in the design of diet software that predicts MPY responses to increased MAA, regardless of whether AA are supplied from dietary protein sources or from rumen-protected AA.

\section{REFERENCES}

AMS-USDA. 1999. General Provisions of Federal Milk Marketing Orders. Agricultural Marketing Service, USDA, Washington, DC.

AMS-USDA. 2009. Milk Marketing Order Public Database. http:// apps.ams.usda.gov/USDAMIB/Main/Welcome.aspx Accessed July $21,2009$.

Armentano, L. E., S. J. Bertics, and G. A. Ducharme. 1997. Response of lactating cows to methionine or methionine plus lysine added to high protein diets based on alfalfa and heated soybeans. J. Dairy Sci. 80:1194-1199.

Bequette, B. J. 2002. Amino acid metabolism in dairy cows. Pages 102-124 in Proceedings of 49th Maryland Nutrition Conference for Feed Manufacturers. Maryland Feed Industry Council, Animal and Avian Sciences Department, University of Maryland, College Park.

Berthiaume, R., P. Dubreuil, M. Stevenson, B. W. McBride, and H. Lapierre. 2001. Intestinal disappearance and mesenteric and portal appearance of amino acids in dairy cows fed ruminally protected methionine. J. Dairy Sci. 84:194-203.

Casper, D. P., and D. J. Schingoethe. 1988. Protected methionine supplementation to a barley-based diet for cows during early lactation. J. Dairy Sci. 71:164-172.

Casper, D. P., D. J. Schingoethe, C. M. J. Yang, and C. R. Mueller. 1987. Protected methionine supplementation with extruded blend of soybeans and soybean meal for dairy cows. J. Dairy Sci. $70: 321-330$.

Cho, J., T. R. Overton, C. G. Schwab, and L. W. Tauer. 2007. Determining the amount of rumen-protected methionine supplement that corresponds to the optimal levels of methionine in metabolizable protein for maximizing milk protein production and profit on dairy farms. J. Dairy Sci. 90:4908-4916.

Doepel, L., D. Pacheco, J. J. Kennelly, M. D. Hanigan, I. F. Lopez, and H. Lapierre. 2004. Milk protein synthesis as a function of amino acid supply. J. Dairy Sci. 87:1279-1297.

Guinard, J., and H. Rulquin. 1994b. Effect of graded levels of duodenal infusions of lysine on mammary uptake of major milk precursors in dairy cows. J. Dairy Sci. 77:3565-3576.

Guinard, J., H. Rulquin, and R. Vérité. 1994a. Effect of graded levels of duodenal infusions of casein on mammary uptake in lactating cows. 1. Major nutrients. J. Dairy Sci. 77:2221-2231.

Illg, D. J., J. L. Sommerfeldt, and D. J. Schingoethe. 1987. Lactational and systemic responses to the supplementation of protected methionine in soybean meal diets. J. Dairy Sci. 70:620-629.

Jensen, R. G. 1995. Handbook of Milk Composition. R. G. Jensen, ed. Academic Press, Toronto, ON, Canada.

King, K. J., W. G. Bergen, C. J. Sniffen, A. L. Grant, D. B. Grieve, V. L. King, and N. K. Ames. 1991. An assessment of absorbable lysine requirements in lactating cows. J. Dairy Sci. 74:2530-2539.

Lapierre, H., R. Berthiaume, G. Raggio, M. C. Thivierge, L. Doepel, D. Pacheco, P. Dubreuil, and G. E. Lobley. 2005. The route of absorbed nitrogen into milk protein. J. Anim. Sci. 80:11-22.

Lapierre, H., D. Pacheco, R. Berthiaume, D. R. Ouellette, C. G. Schwab, P. Dubreuil, G. Holtrop, and G. E. Lobley. 2006. What is the true supply of amino acids for a dairy cow? J. Dairy Sci. 89(E Suppl.):E1-E14.

Lobley, G. E., and H. Lapierre. 2003. Post-absorptive metabolism of amino acids. Pages 737-756 in Progress in Research on Energy and Protein Metabolism, Vol. 109. W. B. Souffrant and C. C. Metges, ed. European Association for Animal Production, Rome, Italy.

Lobley, G. E., X. Shen, G. Le, D. M. Bremner, E. Milne, C. A. Graham, S. E. Anderson, and N. Dennison. 2003. Oxidation of essential amino acids by the ovine gastrointestinal tract. Br. J. Nutr. 89:617-629.

Mabjeesh, S. J., C. E. Kyle, J. C. Macrae, and B. J. Bequette. 2000. Lysine metabolism by the mammary gland of lactating goats at two stages of lactation. J. Dairy Sci. 83:996-1003.

Munneke, R. L., D. J. Schingoethe, and D. P. Casper. 1991. Lactational evaluation of ruminally protected methionine in diets containing extruded soybeans and urea. J. Dairy Sci. 74:227-233.

NRC. 2001. Nutrient Requirements of Dairy Cattle. 7 th rev. ed. Natl. Acad. Sci., Washington, DC.

Pacheco, D., C. G. Schwab, R. Berthiaume, G. Raggio, and H. Lapierre. 2006. Comparison of net portal absorption with predicted flow of digestible amino acids: Scope for improving current models? J. Dairy Sci. 89:4747-4757.

Papas, A. M., J. L. Vicini, J. H. Clark, and S. Peirce-Sandner. 1984. Effects of rumen-protected methionine on plasma free amino acids and production by dairy cows. J. Nutr. 114:2221-2227.

Piepenbrink, M. S., A. L. Marr, M. R. Waldron, W. R. Butler, T. R. Overton, M. Vázquez-Añón, and M. D. Holt. 2004. Feeding 2-hydroxy-4-(methylthio)-butanoic acid to periparturient dairy cows improves milk production but not hepatic metabolism. J. Dairy Sci. 87:1071-1084.

Piepenbrink, M. S., C. S. Schwab, B. K. Sloan, and N. L. Whitehouse. 1999. Importance of dietary concentrations of absorbable lysine on maximizing milk protein production of mid-lactation cows. J. Dairy Sci. 82(Suppl. 1):93. (Abstr.)

Pisulewski, P. M., H. Rulquin, J. L. Peyraud, and R. Vérité. 1996. Lactational and systemic responses to post-ruminal infusions of increasing levels of methionine in dairy cows. J. Dairy Sci. 79:1781-1791.

Polan, C. E., K. A. Cummins, C. J. Sniffen, T. V. Muscato, J. L. Vicini, B. A. Crooker, J. H. Clark, D. G. Johnson, D. E. Otterby, B. Guillaume, L. D. Muller, G. A. Varga, R. A. Murray, and S. B. Peirce-Sandner. 1991. Responses of dairy cows to supplemental rumen-protected forms of methionine and lysine. J. Dairy Sci. 74:2997-3013.

Raggio, G., D. Pacheco, R. Berthiaume, G. E. Lobley, D. Pellerin, G. Allard, P. Dubreuil, and H. Lapierre. 2004. Effect of metabolizable protein on splanchnic flux of amino acids in lactating dairy cows. J. Dairy Sci. 87:3461-3472.

Robbins, K. R., A. M. Saxton, and L. L. Southern. 2006. Estimation of nutrient requirements using broken line regression analysis. J. Anim. Sci. 84(E. Suppl.):E155-E165.

Rogers, J. A., U. Krishnamoorthy, and C. J. Sniffen. 1987. Plasma amino acids and milk protein production by cows fed rumenprotected methionine and lysine. J. Dairy Sci. 70:789-798.

Rulquin, H., and L. Delaby. 1994. Lactational responses of dairy cows to graded amounts of rumen-protected methionine. J. Dairy Sci. 77(Suppl. 1):91. (Abstr.)

Rulquin, H., and L. Delaby. 1997. Effects of the energy balance of dairy cows on lactational responses to rumen-protected methionine. J. Dairy Sci. 80:2513-2522.

Rulquin, H., P. M. Pisulewski, R. Verite, and J. Guinard. 1993. Milk production and composition as a function of postruminal lysine and methionine supply: A nutrient-response approach. Livest. Prod. Sci. 37:69-90.

Schingoethe, D. J., D. P. Casper, C. Yang, D. J. Illg, J. L. Sommerfeldt, and C. R. Mueller. 1988. Lactational response to soybean meal, heated soybean meal, and extruded soybeans with ruminally protected methionine. J. Dairy Sci. 71:173-180.

Schwab, C. G., and S. E. Boucher. 2008. Feeding for and the cost of producing milk components: Milk protein. Pages 103-112 in Proc. 6th Mid-Atlantic Nutrition Conf., Timonium, MD. 
Schwab, C. G., C. K. Bozak, N. L. Whitehouse, and M. M. A. Mesbah. 1992a. Amino acid limitation and flow to the duodenum at four stages of lactation. 1. Sequence of lysine and methionine limitation. J. Dairy Sci. 75:3486-3502.

Schwab, C. G., C. K. Bozak, N. L. Whitehouse, and V. M. Olson. 1992b. Amino acid limitation and flow to duodenum at four stages of lactation. 2. Extent of lysine limitation. J. Dairy Sci. 75:35033518 .

Schwab, C. G., L. D. Satter, and B. Clay. 1976. Response to lactating dairy cows to abomasal infusion of amino acids. J. Dairy Sci. 59:1254-1270

Socha, M. T., C. G. Schwab, D. E. Putnam, N. L. Whitehouse, B. D. Garthwaite, and G. A. Ducharme. 2008. Extent of methionine limitation in peak-, early-, and mid-lactation dairy cows. J. Dairy Sci. 91:1996-2010.

Socha, M. T., C. G. Schwab, D. E. Putnam, N. L. Whitehouse, N A. Kierstead, B. D. Garthwaite, and G. A. Ducharme. 1994a. Determining methionine requirements of dairy cows during early lactation by post-ruminally infusing incremental amounts of methionine. J. Dairy Sci. 77(Suppl. 1):93. (Abstr.)

Socha, M. T., C. G. Schwab, D. E. Putnam, N. L. Whitehouse, N. A. Kierstead, B. D. Garthwaite, and G. A. Ducharme. 1994b. Determining methionine requirements of dairy cows during peak lactation by post-ruminally infusing incremental amounts of methionine. J. Dairy Sci. 77(Suppl. 1):92. (Abstr.)

St-Pierre, N. R. 2001. Invited review: Integrating quantitative findings from multiple studies using mixed model methodology. J. Dairy Sci. 84:741-755

St-Pierre, N. R. 2003. Reassessment of biases in predicted nitrogen flows to the duodenum by NRC 2001. J. Dairy Sci. 86:344-350.

Van Bruchem, J., J. Voigt, T. S. C. W. Lammers-Wienhoven, U. Schönhusen, J. J. M. H. Ketelaars, and S. Tamminga. 1997. Secretion and reabsorption of endogenous protein along the small intestine of sheep: Estimates derived from ${ }^{15} \mathrm{~N}$ dilution of plasma non-protein-N. Br. J. Nutr. 77:273-286.

Wang, C., J. X. Liu, Z. P. Yuan, Y. M. Wu, S. W. Zhai, and H. W. Ye. 2007. Effect of level of metabolizable protein on milk production and nitrogen utilization in lactating dairy cows. J. Dairy Sci. 90:2960-2965.

Whitelaw, F. G., J. S. Milne, E. R. Orskov, and J. S. Smith. 1986. The nitrogen and energy metabolism of lactating cows given abomasal infusions of casein. Br. J. Nutr. 55:537-556.

Yang, C. M. J., D. J. Schingoethe, and D. P. Casper. 1986. Protected methionine and heat-treated soybean meal for high producing dairy cows. J. Dairy Sci. 69:2348-2357. 